\title{
Rub-a-dub-dub, Three Maids in a Tub: Women in Bathhouses and Secondary Sites of Sex Work in Medieval Hungarian Towns
}

\author{
Christopher Mielke \\ Al-Quds Bard College (College for Arts and Sciences), \\ Jerusalem, thechrismielke@gmail.com
}

\section{Abstract}

Sex work in the Middle Ages could occur at an official city brothel, at a bathhouse, in a private residence, or on certain streets. While the locations of municipal brothels are known in five cities from medieval Hungary, little has been discussed about other sites of prostitution. The first part of this paper aims to better understand what kind of women interacted with bathhouses in the Kingdom of Hungary and determine if there is any link between the city brothels. The second aspect explored will be using etymological history to understand the geographic links between brothels, bathhouses, and streets associated with sex work in medieval Hungarian cities.

Keywords: Prostitution; Bathhouses; sexuality; topography; urban history; Hungary; Central Europe; Middle Ages. 


\title{
Rub-a-dub-dub, Three Maids in a Tub: Women in Bathhouses and Secondary Sites of Sex Work in Medieval Hungarian Towns
}

\author{
Christopher Mielke \\ Beverly Heritage Center, USA
}

\section{Introduction}

At present, there are at least five cities from medieval Hungary which would have had an official municipal brothel: Sopron, ${ }^{1}$ Bratislava ${ }^{2}$ (in Slovakia), Prešov (in Slovakia), ${ }^{3}$ Levoča (in Slovakia), ${ }^{4}$ and Brasov (in

\footnotetext{
1 This article will refer to the cities of the former Hungarian kingdom by their current geographic names. The historical names will be indicated in footnotes. Sopron in Latin sources: Sopronium or Scarbantia, German: Ödenburg. Ferenc Jankó, József Kücsán and Katalin Szende, Sopron (Sopron: Soproni Levéltár, 2010), Map A.3.3.

2 Latin: Posonium, German: Preßburg, Hungarian: Pozsony. Judit Majorossy, "A foglalkozás topográfiája: A társadalmi tértől a személyes térig: a társadalmi mobilitás térbeli elemei a 15. századi Pozsonyban" [The Topography of Craft. From Social Space to Personal Space: Elements of Social Mobility in Fifteenth-Century Pressburg], Korall 45 (2011): 122-123.

${ }^{3}$ Latin: Fragopolis or Eperiessinum, German: Eperies or Preschau, Hungarian: Eperjes. This one is known from 1516-1519 and mentioned as lupanar. I am incredibly grateful to Blanka Szeghyová to pointing this one out to me. Prešov State Archives, 2676, folio 37, 39 verso, 61, 87, and 104 .

${ }^{4}$ Latin: Leutsovia, German: Leutschau, Hungarian: Löcse. There is a reference to a "hawsz der freyenweyben" in a document from June 28, 1518 which mentions the brothel as the site where a certain Nicholas Haske offered a pfennig to spend the night with a woman and she returned it because she said she was his mother. Eperjes város levéltára: Középkori gyújtemény (U 430), listed in the Hungarian National Archives (henceforth MNL) as OL, DF 229573. Béla Iványi, "Lőcsei vonatkozású művelődéstörténeti adatok a középkorból” [Cultural history related to Levoča from the Middle Ages], in Közlemények szepes vármegye múltjából [Publications about the history of Szepes County], edited by Jenő Förster, vol. II (Levoča: J. T. Reiss, 1910), 22-23; Gyula Magyary-Kossa, Magyar orvosi emlékeek. [Hungarian medical memories] (Budapest: A Magyar Orvosi Köbyvkiadó, 1929), vol. I, 222.
} 
Romania). ${ }^{5}$ For cases where the location of these houses of ill repute is known, they tended to be near the water, near town gates, and even within the walls of the cities. ${ }^{6}$ However, brothels were not the only sites in medieval towns where activities related to the sex trade took place. Jacques Rossiaud identified four different spaces where sex work took place in the Middle Ages: city-run brothels, bathhouses, smaller private establishments and finally freelance prostitutes who used whatever space was handy. ${ }^{7}$ This paper thus aims to understand not only the role of women as they relate to bathhouses, but also how bathhouses and street names associated with sex work relate to the city brothels. While other urban spaces like taverns operated as sites where not only casual prostitutes met customers, but also where they could be regulars, they will not be explored here. ${ }^{8}$ In building off of Rossiaud's paradigm, this article will focus on sites outside of the brothel where the sex trade took place in the larger cities and free royal towns in medieval Hungary.

In medieval cities, bathhouses were often treated in the same breath as brothels, particularly by urban authorities. Several towns on the

${ }^{5}$ Latin: Corona, German: Kronstadt, Hungarian: Brassó. This institution is referred to as both "lupanar" in 1520 and "prostibulum" in 1522, though in the latter case it is mentioned that it was fitted with iron bars, indicating that it could havebeen a prison. Magyary-Kossa, Magyar orvosi emlékeek, vol. I, 222-223, vol. III, 142. Băldescu's interpretation of the lupanar in Braşov is that, in a Protestant context, it would have been a guesthouse. Irina Băldescu, Transilvania medievală: topografie și norme judice ale cetăților Sibiu, Bistrita, Brasov, Cluj [Medieval Transylvania: topography and judicial norms of Sibiu, Bistrița, Braşov, Cluj] (Bucharest: Simetria, 2012), 259-260. A similar situation is noted in Bardejov (in Slovakia, Latin: Bartpha, German: Bartfeld, Hungarian: Bártfa), where the word "Gefengnis" is used indicating that the building was a prison - indeed, it was on the eastern corner of Buttelgasse, i.e. "prison street". The Latin terminology used to describe the building is "prostibulum", indicating that it might have had multiple uses. Malvina Groszmann, Bártfa város 1418-1444-iki s számadásköyvei müvelödéstörténeti szempontból [The account books of the city of Bártfa from a cultural historical point of view] (Budapest: Minerva, 1911), 16, 43, 46-47. For a greater elaboration on this, see Blanka Szegyhová's essay "Fornicatrices, scortatrices et meretrices diabolares: Disciplining Women in Early Modern Hungarian Towns," in this volume.

${ }^{6}$ Christopher Mielke, "The Best Little Whorehouses in Hungary: The Topography of Brothels in the Free Royal Towns," paper presented at the $45^{\text {th }}$ International Medieval Congress, Leeds, UK, July 2015.

${ }^{7}$ Jacques Rossiaud, Medieval Prostitution (New York: Blackwell, 1995), 5-7.

8 Ruth Mazo Karras, Common Women: Prostitution and Sexuality in Medieval England (Oxford: Oxford University Press, 1996), 71-72. For a paper that delves more closely into the relationship between taverns and prostitution, see Gordan Ravančić, "Prostitution in Late Medieval Dubrovnik," in this volume. 
south coast of England (Sandwich, Southampton, and Southwark) had "stews" which were essentially bathhouses where prostitutes worked and frequented. ${ }^{9}$ The link between bathhouses and brothels in German cities is more ambiguous. There are several urban authorities that imposed restrictions on employing "common women" in bathhouses (like in Wrocław), while other cities (like Lüneburg) reinforced separation of men and women in bathing facilities. In spite of this and isolated incidents like Contz Steinmetz being fined by Dresden in 1494 for bathing with a whore, or a woman from Quedlinburg being punished for bathing with men in 1481, there is little evidence for bathhouses in German cities functioning as brothels. ${ }^{10}$ In the Byzantine world, a woman going to a public bath was akin to her admitting adultery, though in the Russian world baths were by nature a space of mixed genders with no sexual connotation attached. ${ }^{11}$ In addition to bathing, medieval women could go to the bathhouse as part of their wedding journey or to get their hair done. ${ }^{12}$

Bathhouses themselves can be ascribed to a habit of fourteenthcentury towns Guy Geltner calls "healthscaping" - that is, a city's effort to maintain the public health. In his study of Lucca, the town had a governing body in charge of enforcing regulations related to waste disposal, maintenance of public areas, and supervising water drainage (including sewage). ${ }^{13}$ In a way, the attitude of public authorities towards brothels, prostitutes, and bathhouses reflected this same sort of interest in public health. The very public danger of sexuality threatened the social order of medieval towns, which, in turn, led to the publicly sponsored brothel as being a place where the women could be kept and

\footnotetext{
${ }^{9}$ Karras, Common Women, 35-43.

10 Peter Schuster, Das Frauenhaus: städtische Bordelle in Deutschland (1350-1600) (Paderborn: Schöningh, 1992), 129-133.

11 It is presumed that the South Slavic lands in the Balkans had a similar attitude towards baths as the Byzantines, though there is no direct evidence that suggests as such. Eve Levin, Sex and Society in the World of the Orthodox Slavs, 900-1700 (Ithaca: Cornell University Press, 1995), 115-116; 195-197.

${ }^{12}$ Carl Göllner, Siebenbürgische Städte im Mittelalter (Bucharest: Editura Ştiințifică, 1971), 180-181.

13 Guy Geltner, "Healthscaping a medieval city: Lucca's Curia viarum and the future of public health history," Urban History 40/03 (2013): 396-400.
} 
controlled. ${ }^{14}$ Likewise, since bathhouses were often seen as sites where the sex trade could take place, they were under particular scrutiny from authorities, such as the case of the Southwark Stews in England. ${ }^{15}$ This article will thus explore two main issues: first, the question of what involvement women actually had in the bathhouses of the larger Hungarian cities, and second the link between brothels, bathhouses, and street names associated with prostitution.

\section{Women and Bathhouses in medieval Hungary}

\section{Women as founders and builders of bathhouses}

In general, very little is known about who founded public baths and when in medieval Hungary. The earliest known bath from the medieval period is a foundation by Anna (Agnes) of Antioch (d. 1184), wife of Béla III of Hungary (r. 1173-1196). The fact of the foundation itself is known from a later charter from her grandson, Béla IV (r. 1235-1270), originally issued in 1238 wherein this bath already functioning as a public bath (balneum commune) in Esztergom(Latin: Strigonium, German: Gran, Slovak, Ostrihom) was donated to the Hospitaller Order. ${ }^{16}$ This public bath was in a part of Esztergom called Toplica, in the part of the city now known as Hévíz, between the castle hill and the royal town. ${ }^{17}$

${ }^{14}$ Ruth Mazo Karras, "The Regulation of Brothels in Later Medieval England," Signs 14/2 (1989): 401-402.

15 Ibid., 408-411.

16 The original date of this charter was 29 January 1238, though it only survives from a document from 1377. MNL OL DF 106180. "Item confirmauimus eidem domui quedam balnea communia in Strigonio, que fecit fieri auia nostra, bone memorie Domina Anna, secundum normam et libertatem a predecessoribus nostris eidem domui super hoc concessam." Ferdinandus Knauz, et al., Monumenta Ecclesiae Strigoniensis I (Esztergom: Aegydius Horák, 1874), 326; "Item balnea quedam communia, in Strigonio, per Andreae dicti regis Annam [Agnetem] reginam erecta.” György Fejér, Codex diplomaticus Hungariae ecclesiasticus et civilis IX/5 (Buda: 1834), 155; Zsolt Hunyadi, "Hospitaller Commanderies in the Kingdom of Hungary (c. 1150-1330)" in The Military Orders: History and Heritage, ed. by Victoria Mallia-Milanes (Aldershot: Ashgate, 2008), 263 n 38; Zsolt Hunyadi, The Hospitallers in the Medieval Kingdom of Hungary c. 1150-1387 (Budapest: Central European University Press, 2010), 119, 258.

${ }^{17}$ István Horváth, Márta Kelemen and István Torma, Komárom megye régészeti topográfiája: Esztergom és a dorogijárás [The archaeological topography of Komárom County: Esztergom and the district of Dorog] (Magyarország Régészeti Topográfiája 5) 
Anna had been raised not only in the Holy Land (i.e. in Antioch), but also at the Byzantine court in Constantinople; her choice in founding this public bath in all likelihood stems from her background in the Eastern Mediterranean. Bathhouses from the Crusader period are known from Acre, Jaffa, Jerusalem, and Tyre, while one from the thirteenth century was excavated in 'Atlit. ${ }^{18}$ Anna grew up in Antioch, a city where at least four baths are known from the Crusader period. The Byzantine Emperor Manuel I Komnenos (r. 1143-1180) was known to have visited the baths of Antioch in 1159 and Ciggaar surmises that Anna's father Reynald of Châtillon would have accompanied him there as well. ${ }^{19}$ The situation in Komnenos-era Constantinople is more difficult to reconstruct. While baths and bathing were an important part of the city in the Late Antique period, by the twelfth century the city had significantly changed. Rather than the old Great Palace of Constantinople, the Byzantine imperial family inhabited the Blachernae Palace; bathing was an important part of the Friday imperial ceremony here, which ended at the nearby Church of the Theotokos. These baths had burnt down in 1070, a century prior to Anna's arrival in Constantinople. ${ }^{20}$ Her husband, Béla III had been raised at the imperial court in Constantinople, so it could be easy to ascribe her foundation of this public bath to his will; however, charter refers to her as the founder of the bath and the strong presence of bathhouses in Antioch suggest her familiarity with them as civic institutions. All this points to Anna's own initiative with charity and the public health of the city of

(Budapest: Akadémiai Kiadó, 1979), 159-160; Hunyadi, The Hospitallers in the Medieval Kingdom of Hungary, 37, 119.

18 There are also Ayyubid-era bathhouses from Mount Tabor and Jazirat Fara'un and a Mamluk one at Tall Hisban. Denys Pringle, Secular Buildings in the Crusader Kingdom of Jerusalem: An Archaeological Gazetteer (Cambridge: Cambridge University Press, 1997), 13, 22-23; Howard Smithline, Edna J. Stern, and Eliezer Stern, "A Crusader-Period Bathhouse in 'Akko (Acre)," Atiqot 73 (2013): 71-108.

${ }_{19}$ Three of these baths seem mentioned in 1140, while one of the Hospitaller baths is known from a purchase in 1186. Krijnie N. Ciggaar, "Adaptation to Oriental Life by Rulers in and around Antioch: Examples and Exempla," in East and West in the Medieval Mediterranean: Antioch from the Byzantine Reconquest until the End of the Crusader Principality, ed. by Krijnie N. Ciggaar and Victoria D. van Aalst (Leuven: Peeters, 2013), 265-267.

${ }^{20}$ Fikret Yegül, "Baths of Constantinople: An Urban Symbol in a Changing World" in Archaeology and History in Roman, Medieval, and Post-medieval Greece: Studies on Method and Meaning in Honor of Timothy E. Gregory, ed. by William Caraher, Linda Jones Hall, and R. Scott Moore (Burlington: Ashgate, 2008), 183, 191-192. 
Esztergom in mind. What is even more interesting in this regard is that when the builder of a bathhouses are known, usually they are built for private purposes. This is the case for Elisabeth of Poland (d. 1380), wife of Charles I Robert (r. 1308-1342) who built a bath complex in the mid-fourteenth century as part of her building projects at the palace in Óbuda. ${ }^{21}$ While most of what is known about bathhouses dates from the fourteenth century onward, Queen Anna's twelfth-century foundation is an incredibly important milestone as it seems to be the earliest known public bath from the Age of the Árpáds.

\section{Women who owned and operated, and contributed to medieval bathhouses}

The most direct connection between women and public bathhouses relates to those women who either owned the bathhouse or worked as a bath attendant (balneatrix, baderin, fürdös). Starting with women who owned bathhouses, Anna Agendorfer, the widow of Nicholas Weißbacher of Vienna, was listed as the owner of Sopron's "upper bath" in 1417. This particular bath was on Smith Street, directly on the opposite side of the Ikva stream from the city's brothel on Rose Street. ${ }^{22}$ The daughter Martin Agendorfer (the previous owner), Anna apparently sold this bath to a "master bathkeeper" (maisterpader) that

${ }^{21}$ Elizabeth's son Louis I (r. 1342-1382) and JánosVitéz are known to have built baths onto their residences at the royal palace of Visegrád and the archiepiscopal palace of Esztergom respectively. Eva Sniezynska-Stolot, "Queen Elizabeth as a Patron of Architecture," Acta Historiae Artium Academiae Scientiarum Hungaricae 20 (1974): 28; Horváth, Kelemen, and Torma, Komárom megye régészeti topográfiája, 110; Gergely Buzás, "The Functional Reconstruction of the Visegrád Royal Palace", in The Medieval Royal Palace at Visegrád, ed. Gergely Buzás and József Laszlovszky (Budapest: Archaeolingua Press, 2013), 174-181.

22 Two other baths - the "lower" and "middle" baths - were on the same side as the upper bath (and thus similarly on the opposite side of the Ikva). A fourth public bath is known from the city center, at the Fish Market by the gate there. Katalin Kincses, "A soproni fürdők a kora újkorban" [The Baths of Sopron in the Early Modern Period], AETAS Történettudományifolyóirat1 (1997): 17-42 (particularly 21); András Kubinyi, “Orvoslás, gyógyszerészek, fürdők és ispotályok a későközépkori Magyarországon” [Healing, Apothecaries, Baths and Hospitals in Late Medieval Hungary], in Föpapok, egyházi intézmények és vallásosság a középkori Magyarországon [Priests, ecclesiastical institutions and religiosity in medieval Hungary] (Budapest: METEM, 1999), 257-258. 
same year. ${ }^{23}$ In 1477, the owner of the "old bath" in Bratislava was Margareth, the daughter of Niklas Flins; he had been listed as the owner in 1452 and $1464 .{ }^{24}$ In the early 1500s, Margaretha, the widow of Wilhelm Wultzendorfer, owned the upper and lower bathhouses of the same city together with her son. ${ }^{25}$ In Sopron, after the death of the bathmaster of the "middle bath" on Smith Street in 1479, his underage son and the new husband of the former bathmaster's widow are listed as the new tenants. ${ }^{26}$

Women listed as bath attendants appear more often in the sources, though unlike the women owners there is usually less known specifically about them. For instance, in 1379, the widow of the bathkeeper Hans was listed as the bath attendant for the bath near St. Martin's Church in Bratislava. ${ }^{27}$ The town book of Košice mentions three women bathhouse attendants, though the only pertinent information that is recorded about them are payments made to them. Only one is mentioned explicitly by name. ${ }^{28}$ The wife of John Prais, the bathkeeper of Sopron's "upper bath" in the 1430s is listed with her

23 This "upper bath" had been first attested to in the mid-thirteenth century. Károly Mollay, "A Kovácsok utcájának topográfiája (1379-1536)" [The topography of Smith Street (1379-1526)], Soproni Szemle XLIX, 2 (1995): 131.

24 At some point in the 1480 s, this short-lived bath must have been closed down (in 1487 it was already mentioned as an old bath), and when the plot on which it stood was mentioned as the property of a painter named Hans Ambsteter and his wife Margaret it was most probably not functioning as bath any more. Majorossy, "A test és a lélekfürdője”, 351-352, 355.

25 These two baths were at the northern southern end of the city - the upper bath near the Poor Clares cloister and the lower bath near the Fisherman's gate. Majorossy, "A test és a lélekfürdője. A középkori pozsonyi fürdőkről”, 348, 351, 355-356.

${ }^{26}$ To make matters even more confusing, both the widow's young son and her new husband are named John (Hans and Johannes respectively); the widow herself is not named. Mollay, "A Kovácsok utcájának topográfiája (1379-1536)": 152.

27 This bath was on the western edge of the town, near the Wedritz (or in Hungarian Vödric) Gate. Majorossy, "A test és a lélekfürdője”, 348, 352.

28 Latin: Cassoviensis, German: Kaschau, Hungarian: Kassa. "Agnes super filiam paterin XXXVII gs," "Balneatrix debet iurare Johanni quondam Ioannis Stal diner pro XXXIX gs," "Hamman Mager Lasla super paderin III flor". The earliest known bath from Košice is first mentioned in 1385 as the property of several burghers, rather than one owned by the city. Ondrej R. Halaga, Acta Iudiciaria Civitatis Cassoviensis 1393-1405: das älteste Kaschauer Stadtbuch. (Munich: Oldenbourg, 1994), 63, 114, 243; Drahoslav Magdoško, "Samospráva mesta Košice v stredoveku" [The local government of Košice] (PhD. Dissertation: Univerzita Pavla Jozefa Šafárika v Košiciach, 2017), 175. 
husband in the tax records, though by the 1440s she is listed as a widow. ${ }^{29}$ Three women who worked as attendants in the bathhouse of Sibiu (in Romania) were mentioned by name from 1487 onward. ${ }^{30}$

There is finally a third category of women whose interaction with bathhouses comes from a charitable standpoint. While women like the aforementioned Anna of Antioch would belong to this category, in this case it refers to women who left gifts (usually sums of money) for the bathhouses to engage in services to the community. Sometimes these charitable gifts could be to baths that were associated in some way with hospitals. Baths could be attached to a town's hospital, like in the case of Hlohovec (in Slovakia) in $1400 .{ }^{31}$ In 1473, the wife of Thomas the butcher provided a bath and the meal at the "middle bath" of Sopron once a year. A similar proviso was upheld by Barbara Traismaurer, the widow of Count Ladislas Kempnyei in $1482 .{ }^{32}$ In the lease of the "upper bath" of Sopron to the city council dating from October 1488, Conrad (Kirenncz) Stein and his wife Barbara stipulate that bath services will be free to the poor of the hospital on the day after the Fifth Sunday of Easter. ${ }^{33}$ In Prešov, in 1503, a butcher's wife built a room in the city's hospital explicitly for bathing. ${ }^{34}$ Not all charitable donations which involved bathing the poor necessarily involved hospitals, of course. The two institutions (bathhouses and hospitals) are often linked together because they usually shared a sewage system. ${ }^{35}$

While these examples listed are not exhaustive (nor meant to be),

${ }^{29}$ Mollay, “A Kovácsok utcájának topográfiája (1379-1536),” 131.

30 Latin: Cibinium, German: Hermannstadt, Hungarian: Nagyszeben. "Dy Jacob Baderin", "Agneyt dy baderin", "Elisabet dy baderin", "Angneyt dy baddregerin". Ignácz Schwarz, “A fürdök történetéhez Magyarországon.” [The history of baths in Hungary] Századok 25 (1891): 282; Gyula Magyary-Kossa, Magyar orvosi emlékeek. [Memories of Hungarian Medicine] (Budapest: Orvosi Könyvkiadó, 1931), vol. III, 105.

31 Latin: Eleutheropolis, German: Freistadt, Hungarian Galgóc. Majorossy and Szende, "Hospitals in Medieval and Early Modern Hungary", 416-417.

32 ain pad vnd ain mal ins spital", "ain selpad vnd nachdem pad essenn vnd trinkchen nach gewanheit desselben spitals”. Mollay, “A Kovácsok utcájának topográfiája (13791536)": 150 .

33 Mollay, "A Kovácsok utcájának topográfiája (1379-1536)": 133; Kincses, “A sopronifürdők a kora újkorban”: 21.

34 Majorossy and Szende, "Hospitals in Medieval and Early Modern Hungary", 437.

35 This seems to be the case for Sopron, Sibiu, Braşov, and Bistrița (in Romania. German: Bistritz or Nösen, Hungarian: Beszterce). Băldescu, Transilvania medievală, 150, 197-198, 259-260. 
there are a few observations that can be made about the women involved in bathhouses. In several cases, the women associated with the bathhouses are mentioned as being related in some way to another (male) owner or attendant. Anna Agendorfter (the wife of Martin Weißbacher) - the owner of Sopron's "upper bath" in 1417 - was first the daughter of one owner, and later the wife of another owner of the bathhouse, though she would later inherit it and become the owner herself. However, for charitable donations and negotiations over the lease of bathhouses, these activities seem to be done either as joint enterprises between husband and wife, or on the part of the wife while her husband was presumably alive. Women from all walks of life could involve themselves in public baths - workers could join their husbands as attendants, burgher women could inherit or transmit ownership of these bathhouses, and noble and royal women could build or donate to them. It seems that while prostitution may have occurred at bathhouses in Hungarian towns, the women most frequently seen at the bathhouses were more involved in the day-to-day operations rather than in the sex trade. Such incidents would like be just that - incidents. Within the bath complex themselves, there were likely precautions taken against such activities as well. For instance, baths in Sopron and Bratislava would have had a separate bath within the complex just for women. ${ }^{36}$ Towards the end of the sixteenth and seventeenth centuries, clergymen and town officials associated bathhouses with sites of the sex trade, associating them with syphilis and sinfulness and most bathhouses were subsequently closed down. ${ }^{37}$ In spite of this, it appears that many women were involved in the day-to-day running of Hungarian bathhouses, but that does not mean that they were sex workers.

\section{Street names as indicators of prostitution - "Rose Street"}

While bathhouses might not deserve their reputation as sites of the sex trade, there are other topographical features which can provide more information about this part of medieval urban life. In England, some streets with the rather vulgar name of "Gropecunt Lane" have been

\footnotetext{
36 "stuben, da sy dye frawen abziehen" Mollay, "A Kovácsok utcájának topográfiája (1379-1536)": 137-138; Majorossy, “A test és a lélekfürdője”, 352-353.

37 Göllner, Siebenbürgische Städte im Mittelalter, 182.
} 
associated with prostitution. ${ }^{38}$ Other euphemistic street names appear in Germany, such as "Taschengasse" ("Pocket Alley") in Erfurt known from 1587 is most likely a reference to a woman's reproductive organs, indicative that the street was a site of the sex trade. ${ }^{39}$ Yet in most medieval cities (London, for example), "Rose Street" was also associated with prostitutes; "to pluck a rose" was often a synonym for intercourse with a prostitute. ${ }^{40}$ In Sluis, there was even a brothel that had the name La Chapel des Roses from around 1403-1405. ${ }^{41}$ In Frankfurt, Number 1 Rosengasse (i.e. "Rose Alley") was known to have been the city's brothel. ${ }^{42}$ This is a fairly common trope in medieval German cities for a Rosengasse, Rosenstraße or Rosenweg to be associated with prostitution, though there are of course a few exceptions; in the case of Gotha, it seems that the Rosengasse there was named after a garden which actually grew roses. ${ }^{43}$ Nonetheless, in several Thuringian towns, "Rose Street" was connected not only with several known brothels, but also with bathhouses; often, a Rosengasse was parallel to a Badergasse. ${ }^{44}$ If a "Rose Street" appears in some peripheral place or near the city's wall, it is more likely to be connected to prostitution.

Hungarian towns borrowed not only legal structures but also people

38 Richard Holt and Nigel Baker, "Towards a geography of sexual encounter: prostitution in English medieval towns" in Indecent Exposure: Sexuality, Society, and the Archaeological Record., ed. by L. Bevin (Glasgow: Cruithne Press, 2001), 201-215; Keith Briggs, "OE and ME cunte in place-names" Journal of the English Place-name Society 41 (2009): 26-39.

39 Pascal Mauf and Martin Sladeczek, "Straßennamen des städtischen Randes" Namenkundliche Informationen 101/102 (2012/2013): 338.

40 Jeffrey Richards, Sex, Dissidence and Damnation: Minority Groups in the Middle Ages (New York: Routledge, 1991), 116.

${ }^{41}$ It was first known as "The Parrot", then later referred to as "La Chapel de rose ou Papegay". Erik Spindler, "Were Medieval Prostitutes Marginals? Evidence from Sluis, 1387-1440." Revue belge de philologieetd'bistoire 87 (2009): 248.

42 Kriegk does not specify when this was the site of the city's brothel, though presumably he means the Middle Ages. Georg Ludwig Kriegk, Deutsches Bürgerthum im Mittelalter (Frankfurt: Rütten and Löning, 1868), 258.

43 The same seems to be true for the Rosenstraße in Eisenach. Mauf and Sladeczek, "Straßennamen des städtischen Randes", 334, 338.

44 The public bath in Bistriţa was found on a Badergasse. Băldescu, Transilvania medievală, 259-260. Like the brothels, these streets could often be peripheral, but in a few cases brothels could occupy a very central location in town, such as in Erfurt. Mauf and Sladeczek, "Straßennamen des städtischen Randes", 334-338. 
from German towns, ${ }^{45}$ and the towns surveyed here follow western examples insofar as the topographical appearance of "Rose Streets." Being one of the better documented Hungarian cities, Sopron is the best example of this sort of phenomenon. While the three bathhouses are on Smith street (i.e. Schmiedgasse) in the first ring of Sopron's suburbs, the city's brothel is across a little brook on a street called Rosengasse (i.e. Rózsa utca or Rose Street). The houses on this street date mostly from 1330 to 1380 and the back ends of these establishments faced each other. ${ }^{46}$ Two documents from 1499 refer to a "street of the roses" (via rosarum) in the city of Buda, though regrettably the location of this street cannot be identified any further. ${ }^{47}$ In the city of Cluj-Napoca (in Romania), a Rosengasse appears in the fourteenth century as being inside the city walls, but on the border of the old city. ${ }^{48}$ This is particularly noteworthy considering that when a new bathhouse was erected in the city in 1557, there were particular rules and regulations in place meant to protect the bath from being exposed to either sewage or prostitution. ${ }^{49}$ While the exact topographical relationship between the bathhouse and the Rose Street is difficult to determine at present, this nonetheless shows the anxieties the city authorities had about the intersection of bathing and prostitution.

While many modern Hungarian cities show the presence of a "Rose Street," the urban context must be kept in mind. The city of Levoča has a Rosengasse which is attested to in the later eighteenth century that conforms to the patterns in other cities of being on the urban fringes,

\footnotetext{
45 Laurențiu Rădvan, At Europe's Borders: Medieval Towns in the Romanian Principalities (Leiden and Boston: Brill, 2010), 57-61.

46 Jankó, Kücsán and Szende, Sopron, Map A.3.3. One bathhouse in Sibiu was also located on a similarly named street, Schmiedergasse. Băldescu, Transilvania medievală, 150.

47 András Végh, Buda város középkori helyrajza [A plan of the medieval city of Buda] I (Budapest: Budapest History Museum, 2006), 83.

${ }^{48}$ Latin: Claudiopolis, German: Klausenburg, Hungarian: Kolozsvár. Paul Niedermaier, Städtebau im Spätmittelalter: Siebenbürgen, Banat und Kreischgebiet (1348-1541) (Cologne, Weimar and Vienna: Böhlau Verlag, 2004), 103.

${ }^{49}$ Unfortunately the location of this bathhouse has not been determined at present. Magyary-Kossa, Magyar orvosiemlékeek, 189; Băldescu, Transilvania medievală, 304. There was at least one other bathhouse in Cluj Napoca as evidenced by a lawsuit mentioning city bathkeepers in 1467. Majorossy and Szende, "Hospitals in Medieval and Early Modern Hungary", 410, n5.
} 
literally one street in from the town walls..$^{50}$ As there are references to baths in Levoča in the fifteenth century ${ }^{51}$ as well as a brothel in the sixteenth, it is possible that knowledge about the current Rose Street might help in locating the other institutions. Tied to this issue of geographic proximity is also the question of shared resources. One of the reasons that bathhouses, hospitals, and even some brothels appear to be clustered together is the simple fact that they are close to sources of water. ${ }^{52}$ There is still much work to be done, but the examples of Sopron, Buda, and possibly Cluj-Napoca and Levoča show how the sex trade can be detected in medieval Hungarian cities outside the municipal brothel

\section{Conclusion}

The ultimate question in this article has been about what sort of women were associated with bathhouses and what features in the urban landscape could impart more information on the medieval sex trade. For the first part, there is practically no evidence for prostitution occurring in bathhouses, although it was a concern for town authorities in the sixteenth century. Sopron and Bratislava have a brothel adjacent to at least one of the city's baths, but aside from that there is little connection known. This is hardly a smoking gun considering that the proximity of such institutions could be attributed to something as simple as the water supply. The only women mentioned in connection with the city bathhouses seem to be widows or daughters who took

\footnotetext{
${ }^{50}$ The current name of the street is Ružová. Johann Matthias Korabinsky, Geographischhistorisches und Produkten-Lexikon von Ungarn (Pressburg: Weber and Korabinsky, 1786), 369. The Transylvanian town of Sebeș (in Romania, Latin: Sabesium, German: Mühlbach, Hungarian: Szászsebes) has a very centrally located "Rosengasse" first attested to in 1705; the street is currently called Strada 24 Ianuarie. Călin Anghel, Evolutia urbanistică a oraşului Sebeş. [Urban Development of Sebeş] (Sebeș: Muzeul municipal "Ioan Raica", 2011), 152, 221, 256; Adina-Lucia Nistor, "Das Bild des Anderen in den Straßennamen von Mühlbach. Siculorumgasse, Griechengasse, Opricestengasse, Str. Saxonii Noi” Germanistische Beiträge 36 (2015): 172.

51 Several city baths were given to the Carthusians. Magyary-Kossa, Magyar orvosiemlékeek, 98.

52 This seems to be particularly the case for bathhouses and hospitals being so close together, as evidenced particularly in Sopron and Bratislava. Majorossy and Szende, "Hospitals in Medieval and Early Modern Hungary", 437; Majorossy, "A test és a lélekfürdője," 347.
} 
over ownership and maintenance, or wealthier noblewomen and burghers who offered donations in order to care for the poor. An exceptional example of this is the early case of the twelfth-century foundation of the public bathhouse in Esztergom by Queen Agnes.

Examining the evidence of street names and prostitution, while there are only a handful of examples to work from, there does seem to be an association, though only in the larger cities. The "Rose Streets" seem to be in relatively marginal areas of the town (though often within the city walls) reinforcing ideas about medieval cities trying to push prostitutes towards the edge of the city rather than having them in the center. Curiously enough, in the German cities mentioned earlier, there are several towns where the city's bathhouse is on "Rose street," indicating an unofficial link between the bathhouse and the presence of prostitutes plying their trade outside the city's brothel. While there is no "smoking gun" in most Hungarian cities proving the link between brothels, bathhouses and "Rose Streets," this holistic approach to urban geography should be kept in mind when reconstructing the history of prostitution. Ultimately, a nuanced approach to the women affiliated with bathhouses as well as their urban environs will be the best course of action in studying the medieval sex trade.

\section{Acknowledgments}

I would like to thank Ruth Mazo Karras, Judit Majorossy, and Blanka Szegyhova for their thoughtful remarks on this article. I would like to thank the Medieval Studies Department at Central European University for their aid in hosting the "Forgotten Women from a Forgotten Region" conference in May of 2017 which brought to light several of the pieces published in this volume. I would also like to thank Gerhard Jaritz, Kyra Lyublyanovics, and Katalin Szende for their help with the conference as well.

\section{References}

\section{Primary Sources}

Fejér, György. Codex diplomaticus Hungariae ecclesiasticus et civilis. Vol. I-XI.

Buda: Typis Typogr. Regiae Universitatis Ungaricae, 1829-1844.

Groszmann, Malvina. Bártfa város 1418-1444-iki s számadásköyvei 
müvelódéstörténeti szempontból [Books of the city of Bártfa from a cultural historical point of view]. Budapest: Minerva, 1911.

Halaga, Ondrej. Acta indiciaria civitatis Cassoviensis 1393-1405: das Älteste Kaschauer Stadtbuch. Munich: Oldenbourg, 1994.

Knauz, Ferdinandus et al. Monumenta Ecclesiae Strigoniensis. Vol. I-IV.

Esztergom: Aegydius Horák and Archivum Primatiale, 1874-1999.

\section{Secondary Sources}

Anghel, Călin. Evoluţia urbanistică a oraşului Sebeş [Urban Development of Sebeş]. Sebeş: Muzeul municipal "Ioan Raica", 2011.

Băldescu, Irina. Transilvania medieval: topografie şi norme judice ale cetăților Sibiu, Bistriţa, Braşov, Cluj [Medieval Transylvania: topography and judicial norms of Sibiu, Bistriţa, Braşov, Cluj]. Bucharest: Simetria, 2012.

Briggs, Keith. "OE and ME cunte in place-names." Journal of the English Place-name Society 41 (2009): 26-39.

Buzás, Gergely. "The Functional Reconstruction of the Visegrád Royal Palace." In The Medieval Royal Palace at Visegrád, ed. Gergely Buzás and József Laszlovszky, 141-196. Budapest: Archaeolingua Press, 2013.

Ciggaar, Krijnie N. "Adaptation to Oriental Life by Rulers in and Around Antioch." In East and West in the Medieval Mediterranean: Antioch from the Byzantine Reconquest until the End of the Crusader Principality, ed. Krijnie N. Ciggaar and Victoria D. van Aalst, 261282. Leuven: Peeters, 2013.

Geltner, Guy. "Healthscaping a medieval city: Lucca's Curia viarum and the future of public health history." Urban History 40 (2013): 395415.

Göllner, Carl. Siebenbürgische Städte im Mittelalter. Bucharest: Editura Ştiințifică, 1971.

Holt, Richard and Nigel Baker. "Towards a geography of sexual encounter: prostitution in English medieval towns." In Indecent Exposure: Sexuality, Society, and the Archaeological Record, ed. L. Bevin, 201-215. Glasgow: Cruithne Press, 2001.

Horváth, István, Márta Kelemen and István Torma. Komárom megye régészeti topográfiája: Esatergom és a dorogi járás [The Archaeological topography of Esztergom County: Esztergom and the District of 
Dorog]. (Magyarország Régészeti Topográfiája 5) Budapest: Akadémiai Kiadó, 1979.

Hunyadi, Zsolt. "Hospitaller Commanderies in the Kingdom of Hungary (c. 1150-1330)." In The Military Orders: History and Heritage, ed. Victoria Mallia-Milanes, 253-268. Aldershot: Ashgate, 2008. . The Hospitallers in the Medieval Kingdom of Hungary c. 1150-1387. Budapest: Central European University Press, 2010.

Iványi, Béla. "Lőcsei vonatkozású művelődéstörténeti adatok a középkorból" [Cultural history related to Levoča from the Middle Ages]. In Közllemények szepes vármegye múltjából [Publications about the history of Szepes County], vol. 2, ed. Jenő Förster, 20-23. Levoča: J. T. Reiss, 1910.

Jankó, Ferenc, József Kücsán and Katalin Szende, ed. Sopron. Sopron: Soproni Levéltár, 2010.

Karras, Ruth Mazo. "The regulation of brothels in later medieval England." Signs: Journal of Women in Culture and Society 14 (1989): 399433.

. Common Women: Prostitution and Sexuality in Medieval England. Oxford: Oxford University Press, 1996.

Kincses, Katalin. "A soproni fürdők a kora újkorban” [The Baths of Sopron in the Early Modern Period]. AETASTörténettudományifolyóirat 1 (1997): 17-48.

Korabinsky, Johann Matthias. Geographisch-historisches und ProduktenLexikon von Ungarn. Pressburg: Weber and Korabinsky, 1786.

Kriegk, Georg Ludwig. Deutsches Bürgerthum im Mittelalter. Frankfurt: Rütten and Löning, 1868.

Kubinyi, András. “Orvoslás, gyógyszerészek, fürdők és ispotályok a késő középkori Magyarországon” [Healing, Apothecaries, Baths and Hospitals in Late Medieval Hungary]. In Föpapok, egyházi intézmények és vallásosság a középkori Magyarországon [Priests, Ecclesiastical Institutions and Religiosity in Medieval Hungary], 253-267. Budapest: METEM, 1999.

Levin, Eve. Sex and Society in the World of the Orthodox Slavs, 900-1700. Ithaca: Cornell University Press, 1995.

Magdoško, Drahoslav. "Samospráva mesta Košice v stredoveku” [The local government of Košice]. PhD. Dissertation, Univerzita Pavla Jozefa Šafárika v Košiciach, 2017.

Magyary-Kossa, Gyula. Magyar orvosi emlékeek [Memories of Hungarian 
Medicine], vol. I-IV. Budapest: A Magyar Orvosi Könyvkiadó, 1929-1931.

Majorossy, Judit and Katalin Szende. "Hospitals in Medieval and Early Modern Hungary." In Europäisches Spitalwesen. Institutionelle Fürsoge in Mittelalter und Früber Neureit/Hospitals and Institutions in Medieval and Early Modern Europe, ed. Martin Scheutz, Andrea Sommerlechner, Herwig Weigl and Alfred Stefan Weiß, 409-454. Vienna:

Oldenbourg, 2008.

Majorossy, Judit. “A foglalkozás topográfiája. A társadalmi tértôl a személyes térig: a társadalmi mobilitás térbeli elemei a 15. századi Pozsonyban" [The topography of craft. From social space to personal space: Elements of social mobility in fifteenth-century Pressburg]. Korall 45 (2011): 102-135.

[Bath of the body and the spirit. On the medieval baths in Pressburg]. In "Köztes-Európa” vonzásában: Ünnepi tanulmányok Font Márta tiszteletére, ed. Dániel Bagi, Tamás Fedeles and Gergely Kiss, 343-356. Pécs: Kronosz, 2012.

Mauf, Pascal and Martin Sladeczek. "Straßennamen des städtischen Randes.” Namenkundliche Informationen 101/102 (2012/2013): 332-351.

Mielke, Christopher. "The Best Little Whorehouses in Hungary: The Topography of Brothels in the Free Royal Towns", Paper presented at the 45th International Medieval Congress, Leeds, UK, July 2015.

Mollay, Károly. "A Kovácsok utcájának topográfiája (1379-1536)" [The topography of Smith Street (1379-1526]. Soproni Szemle XLIX, 2 (1995): 130-157.

Niedermaier, Paul. Städtebau im Spätmittelalter: Siebenbürgen, Banat und Kreischgebiet (1348-1541). Cologne, Weimar and Vienna: Böhlau Verlag, 2004.

Nistor, Adina-Lucia. "Das Bild des Anderen in den Straßennamen von Mühlbach. Siculorumgasse, Griechengasse, Opricestengasse, Str. Saxonii Noi." Germanistische Beiträge 36 (2015): 169-183.

Pringle, Denys. Secular Buildings in the Crusader Kingdom of Jerusalem: An Archaeological Gazetteer. Cambridge: Cambridge University Press, 1997.

Rădvan, Laurențiu. At Europe's Borders: Medieval Towns in the Romanian Principalities. Leiden and Boston: Brill, 2010. 
Ravančić, Gordan. "Prostitution in Late Medieval Dubrovnik." In Same Bodies, Different Women: 'Other' Women in the Middle Ages and the Early Modern Period, ed. Christopher Mielke and Andrea-Bianka Znorovszky. Budapest: Trivent, 2018. same volume.

Richards, Jeffrey. Sex, Dissidence and Damnation: Minority Groups in the Middle Ages. New York: Routledge, 1991.

Rossiaud, Jacques. Medieval Prostitution. New York: Blackwell, 1995. Schuster, Peter. Das Frauenhaus: städtische Bordelle in Deutschland (13501600). Paderborn: Schöningh, 1992.

Schwarz, Ignácz. "A fürdök történetéhez Magyarországon" [The history of baths in Hungary]. Századok 25 (1891): 279-296.

Smithline, Howard, Edna J. Stern, and Eliezer Stern. "A CrusaderPeriod Bathhouse in "Akko (Acre)." Atiqot 73 (2013): 71-108.

Sniezynska-Stolot, Éva. "Queen Elizabeth as a Patron of Architecture." Acta Historiae Artium Academiae Scientiarum Hungaricae 20 (1974): 1336.

Spindler, Erik. "Were Medieval Prostitutes Marginals? Evidence from Sluis, 1387-1440." Revue belge de philologie et d'histoire 87 (2009): 239272.

Szegyhová Blanka. "Fornicatrices, scortatrices et meretrices diabolares:

Disciplining Women in Early Modern Hungarian Towns." In Same Bodies, Different Women: 'Other' Women in the Middle Ages and the Early Modern Period, ed. Christopher Mielke and Andrea-Bianka Znorovszky. Budapest: Trivent, 2018. same volume.

Végh, András. Buda város középkori helyrajza [The medieval topography of the city of Buda], Vol. I. (Monumenta Historica Budapestinensia 15-16). Budapest: Budapest History Museum, 2006-2008.

Yegül, Fikret. "Baths of Constantinople: An Urban Symbol in a Changing World." In Archaeology and History in Roman, Medieval, and Post-medieval Greece: Studies on Method and Meaning in Honor of Timothy E. Gregory, ed. William R. Caraher, Linda Jones Hall, and R. Scott Moore, 169-195. Burlington: Ashgate, 2008. 